Acta medico-historica Rigensia (1992) I: 324-328

DOI: 10.25143/amhr.1992.I.26

\title{
БОРИС ДМИТРИЕВИЧ ПЕТРОВ
}

15-го января 1991 года на $87-$ м году ушел из жизни Борис Дмитриевич Петров - доктор медицинских наук, профессор, член-корреспондент АМН СССР. Около 40 лет он являлся лидером советской истории медицины и с достоинством ее представлял на международной арене.

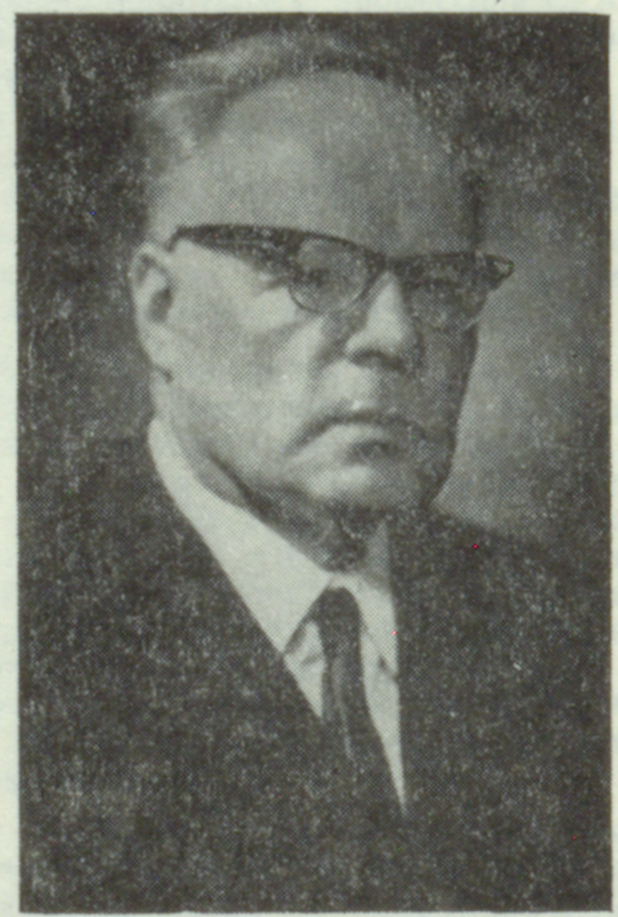

Деятельность Бориса Дмитриевича в области истории медицины исключительна, уникальна и представляет собой целый период ее развития с присущими ему характерными чертами. 
Он родился 4 марта 1904 года в Москве, в 1919 г. подростком начал работать, прошел путь, типичный для значительной части советской интеллигенции, вступившей в жизнь в первые послереволюционные годы: в 1921 г. окончил рабфак, в 1927 г. - медицинский факультет 2-го Московского государственного университета.

Важное значение в формировании личности Бориса Дмитриевича как врача и ученого имело прохождение аспирантуры на кафедре социальной гигиены 2-го МГУ, руководимой 3. П. Соловьевым, и в дальнейшем активное участие в общественной и партийной (член КПСС с 1932 г.) деятельности.

С 1938 по 1948 г. он возглавлял сектор здравоохранения ЦК ВКП(б), а в последующем, с 1948 по 1952 г., являлся ректором Первого Московского медицинского института (ныне Московская Медицинская академия им. И. М. Сеченова) и одновременно руководил кафедрой социальной гигиены ЦОЛИУВ.

С 1949 г. и почти до конца своих дней Борис Дмитриевич руководил отделом историп медицины и советского здравоохранения НИИ им. А. Н. Семашко Министерства здравоохранения СССР.

В своей деятельности ученого и организатора научных исследований он несомненно отразил особенности эпохи, вошедшей в историю, как период административно-командного строя со всеми его негативными проявлениями, неизбежнолнашедшими отражение в деятельности Бориса Дмитриевича. Однако, следуя мудрому совету древних de mortuis aut bene, aut nihil, мы не станем, отдавая последнюю дань ушедшему, перечислять с позиций сегодняшнего дня обусловленные временем некоторые особенности его деятельности, а вспомним более весомые черты, характеризующие этого несомненно выдающегося деятеля советской науки и культуры. Их вспомнить, к счастью, и нетрудно, они на виду.

Борис Дмитриевич вошел в нашу память прежде всего как учитель и воспитатель кадров советских историков медицины. Считанные единицы найдутся в этой среде тех, кто не получил в своем становлении его поддержки. Для многих он являлся добрым советчиком и консультантом, для других - рецензентом и оппонентом при защите диссертаций.

Не замыкаясь в столичные рамки, он распространил 
свою деятельность на все республики. Его часто видели в Риге и Тбилиси, Ереване и Тарту, Ташкенте и Киеве, Минске и Душанбе, Кишиневе и Вильнюсе. Всюду, где нужно было оказать помощь вновь создаваемым кафедрам, обществам, музеям, отдельным работникам, он щедро помогал советами и литературой.

Когда в послевоенные годы остро встал вопрос о создании качественной историко-медицинской литературы, коей либо вовсе не было, либо появлялись недоброкачественные литературные плагиаты, Борис Дмитриевич взял на себя руководство решением данной задачи. Он возглавил подобранный им коллектив авторов, создавший опубликованный в 1954 г. труд «История медицины. Материалы к курсу». Несмотря на имеющуюся на некоторых его страницах дань идеологическим установкам того времени в виде грубых нападок на космополитизм и т. п., книга в своем основном научном содержании являлась необходимой и полезной.

Исключительное значение имело связанное с деятельностью Бориса Дмитриевича возобновление регулярного участия возглавлявшихся им советских делегаций в международных историко-медицинских конгрессах. Он являлся действительным членом Международной Академии истории медицины и национальным делегатом СССР в Международном обществе историков медицины. Неоспоримая заслуга Бориса Дмитриевича в организации регулярных историко-медицинских симпозиумов СССР-ГДР.

$\mathrm{He}$ ограничиваясь вопросами истории медицины, он активно участвовал в подготовке руководящих кадров советского здравоохранения, возглавлял в ЦОЛИУВ факультет усовершенствования руководящих кадров и кафедру организации здравоохранения.

Будучи ответственным работником аппарата ЦК ВКП(б), он, между прочим, используя свои возможности, содействовал направлению на научную и педагогическую работу некоторых видных ученых, которым в те годы угрожали репрессии. Среди них нужно назвать Н. Я. Новомбергского, видного юриста и историка. Лишь благодаря активному участию Б. Д. Петрова, он был избавлен от сибирской ссылки и назначен на кафедру в Архангельский педагогический институт, а также возобновил чтение лекций по истории медицины Древней Руси. 
Несомненным достоинством Бориса Дмитриевича являлось то обстоятельство, что, в отличие от многих «руководящих лиц», он никогда не приписывал себе научные работы и публикации сотрудников, хотя участвовал в их подготовке своими советами и рекомендациями. Все публикации Бориса Дмитриевича - результат личного труда.

В качестве декана ЦИУ (ныне ЦОЛИУВ) и ректора 1-го ММИИ (ныне Медицинской Академии) он возродил традицию «актовых лекций», что имело важное научное и культурное значение.

Перу Бориса Дмитриевича принадлежат ежегодные критико-аналитические обзоры выполненных историкомедицинских исследований, имевшие важное стимулирующее влияние на дальнейшее развитие научной работы.

Первые публикации Бориса Дмитриевича имели место в 1924 г. и были посвящены научной организации труда (HOT). Последняя опубликованная работа - «От Гиппократа до Семашко. Преемственность идей (М., 1990). Bсего его перу принадлежит около тысячи научных публикаций.

Из вопросов, изучавшихся Борисом Дмитриевичем, большое место занимает проблема «народной медицины», явившаяся темой его докторской диссертации, а также деятельность великого ученого-медика и энциклопедиста средневекового Востока Ибн-Сины (Авиценны). Из отечественных ученых большое внимание он уделял научному наследию С. П. Боткина, Ф. Ф. Эрисмана, И. И. Мечникова и основоположников советского здравоохранения Н. А. Семашко и 3. П. Соловьева, бывшего его непосредственным учителем.

Особые долголетние связи были у Бориса Дмитриевича с Музеем истории медицины им. П. Страдыня и историками медицины Латвии. Қак уже отмечалось в литератуpe (см. сб. «Из истории медицины», т. XIV, стр. 143 и сл., Рига, 1984), он активно помогал П. Страдыню в принципиальном решении вопроса о созднии музея в высших партийных инстанциях республики и в составлении экспозиционных планов развертывания музея.

На протяжении долгих лет он был частым и желанным гостем музея, помогал своими советами при решении многообразных задач, стоявших перед коллективом музея. Борис Дмитриевич принимал участие в торжественной церемонии открытия музея для широкой публи- 
ки 20 июня 1961 г. и выступил с актовой речью «История медицины на новом этапе». Он являлся активным участником всех семинаров, симпозиумов, конференций, проводившихся в музее в эти годы.

Борису Дмитриевичу принадлежит важная роль в деле популяризации Музея им. П. Страдыня и установлении научных связей его с советской и зарубежной научной общественностью.

Особый интерес он проявлял к основанному П. Страдынем сборнику «Из истории медицины», являющемуся до настоящего времени единственным регулярным изданием, посвященным истории медицины.

9-го февраля 1984 г. в конференц-зале музея на традиционных Страдыневских чтениях в торжественной обстановке Б. Д. Петрову по решению ученого совета музея была вручена награда им. П. Страдыня, «за выдающийся вклад в историю медицины, содержавшийся в опубликованных трудах, и развитие международного сотрудничества в области истории медицины».

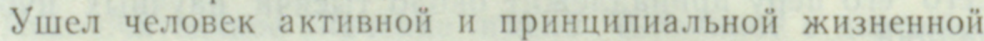
позиции, широкой творческой инициативы и энергии, обширной эрудиции, глубокого знания проблем социальной гигиены и истории медицины.

Медицинская общественность, работники здравоохранения и историки медицины хранят добрую память о неутомимой и плодотворной деятельности Бориса Дмитриевича Петрова, человека и ученого.

Академик АМН России проф. В. В. Капеп Dr. med. А. Н. Хазанов 